\title{
Semi-automated Phenotyping of Soybean Seedlings and Its Relation With Physiological Seed Quality
}

\author{
Jackson Araújo da Silva ${ }^{1}$, André Dantas de Medeiros ${ }^{2}$, Daniel Teixeira Pinheiro ${ }^{2}$, Marcio Dias Pereira ${ }^{1}$, \\ Laércio Junio da Silva $^{2}$, João Paulo Ribeiro ${ }^{2}$, Kamylla Calzolari Ferreira ${ }^{2} \&$ Izabelle Rodrigues Ferreira Gomes $^{1}$ \\ ${ }^{1}$ Department of Agronomy, Federal University of Rio Grande do Norte, Natal, Rio Grande do Norte, Brazil \\ ${ }^{2}$ Department of Fitotecnia, Federal University of Viçosa, Viçosa, Minas Gerais, Brazil \\ Correspondence: Jackson Araújo da Silva, Department of Agronomy, Federal University of Rio Grande do Norte, \\ Natal, RN, Brazil. Tel: 55-313-612-4437. E-mail: jacksonas22@hotmail.com
}

Received: May 20, 2019

doi:10.5539/jas.v11n16p1
Accepted: July 13, 2019 Online Published: September 30, 2019

URL: https://doi.org/10.5539/jas.v11n16p1

The research is financed by Conselho Nacional de Desenvolvimento Cientifico e Tecnológico (CNPq).

\begin{abstract}
The development of procedures enabling agility and effectiveness to the analyses of seed vigor are great advances for the seed research field. The aim of this paper was to evaluate the efficiency of the Seedling Analysis System $\left(\mathrm{SAPL}^{\circledR}\right)$ to seedling phenotyping and determining the physiological potential of soybean seeds, in comparison with the information provided by traditional vigor tests recommended for this species. The characterizing of physiological potential of the seed lots was carried out based on germination tests, first germination count, seedling emergence, cold test, and electrical conductivity. The results of these tests were compared with the data obtained using image analysis with the software SAPL ${ }^{\circledR}$, which was used to evaluate the development seven- day old seedlings. It was obtained the length of shoot, primary root and entire seedling, growth rates, uniformity, vigor index and corrected vigor index, based on different variations of the growth/uniformity ratio, namely 80:20, 70:30, 60:40, in the vigor index calculation. Analysis of images of the seven-day old seedlings using SAPL ${ }^{\circledR}$ enables phenotyping of soybean seedlings and is a consistent and promising alternative for identifying differences in vigor between soybean seed lots, equivalent to that found with traditional vigor tests.
\end{abstract}

Keywords: Glycine $\max$ (L.) Merrill, seed physiological quality, computational vision, seed technology

\section{Introduction}

The soybean [Glycine $\max (\mathrm{L}$.) Merrill] is one of the most important agricultural commodities in Brazil, mainly due to the volume produced and exported (Bornhofen et al., 2015). Thus, the demand for seeds exceeds 1 million tons per year (FAO, 2014).

Seed quality has direct implication on the establishment of the crop in the field and can have consequences for production. Thus, the use of seeds with high physiological quality is essential to ensuring proper performance of the plants, contributing to the final crop yield and the product quality (Marcos Filho, 2015).

Conventionally, evaluating the physiological quality of soybean seeds involves manual methods, such as counting germinated seed, visual tissue analysis in the tetrazolium test and measurement of the length of seedling structures. Although efficient, these methods are laborious, subjective, and prone to human error, and are often unsuitable for large-scale testing.

In recent years, research in seed technology has prioritized high-throughput seedling phenotyping to evaluate seed vigor in order to minimize these limitations in the analyses. Robust semi-automated phenotyping systems capable of generating reliable data have been shown to be efficient for evaluating squash (Silva et al., 2017), onion (Gonçalves et al., 2017), carrot (Marchi \& Cicero, 2017), crambe (Leão-Araújo et al., 2017), corn (Castan et al., 2018; Medeiros et al., 2018), soybean seedlings (Medeiros \& Pereira, 2018; Wendt et al., 2017; Yagushi et al., 2014), among others. 
Among the options available for this purpose is the Seedling Analysis System $\left(\mathrm{SAPL}^{\circledR}\right)$. SAPL ${ }^{\circledR}$ is digital seedling imaging software that analyzes and measures the individual length of shoot, root and total seedling in a fully automated way (Medeiros \& Pereira 2018). With these phenotypic parameters, the software generates uniformity, growth and vigor indexes for each evaluated seed lot. Images can be acquired from cameras or smartphones, and needs a simple, practical and low-cost image acquisition structure.

The quality indexes generated by SAPL ${ }^{\circledR}$ are based on the formulas described by Sako et al. (2001). The growth index (generated from the hypocotyl and root length sample means) and the uniformity index (based on the standard deviation of the seedling length and that of its parts, as well as on the relation between them) are used to calculate the vigor index, based on a previously established proportion between them. The most consistent results in other software were obtained using the proportions of 70:30 (growth:uniformity) for sweet corn (Gomes Junior et al., 2009), 60:40 to 80:20 for cucumber (Chiquito et al., 2012), 30:70 to 70:30 for beans (Gomes Junior et al., 2014).

Previous studies have used SAPL ${ }^{\circledR}$ to analyze soybean seedlings four and six days after the test start (Medeiros \& Pereira, 2018), however, there are no studies that prove the efficiency of any software for reading soybean seedlings after six-day old. Evaluation of seven-day old soybean seedlings may be valid in studies desiring information on the growth of seedlings in more advanced stages. Moreover, there are no papers with SAPL ${ }^{\circledR}$ evaluating different types of proportion of uniformity and growth contributions for the vigor index.

In this context, this work aimed to evaluate the efficiency of the Seedling Analysis System (SAPL $\left.{ }^{\circledR}\right)$ in phenotyping of seven-day old soybean seedling and in determining the physiological quality of soybean seed lots, in comparison with the information provided by the traditional vigor tests recommended for this species.

\section{Material and Methods}

The research was conducted with four soybean seed lots from the region of Unaí, State of Minas Gerais, characterized by the laboratory tests described below.

Degree of moisture: determined by the oven method at $105 \pm 3{ }^{\circ} \mathrm{C}$ for 24 hours, using two replicates of $50 \mathrm{~g}$ of seeds for each lot (Brasil, 2009), with results was expressed as percentage.

Germination test: conducted with four replicates of 50 seeds per lot, on rolls of paper towels moistened with water equivalent to 2.5 times the dry paper mass and kept in a germinator at a constant temperature of $25^{\circ} \mathrm{C}$. The final count was done on the eighth day after sowing (Brasil, 2009) and the results were expressed as the mean percentage of normal seedlings.

First germination count: conducted in conjunction with the germination test. Consisted in counting the percentage of normal seedlings on the fifth day after sowing (Brasil, 2009).

Seedling emergence: carried out with four replicates of 50 seeds in polystyrene trays of multiple cells, one seed per cell being filled with washed sand, irrigated daily and kept in a greenhouse. Final evaluation of the emergence was performed 14 days after sowing, when the total emergence of the seedlings occurred, expressing the result in percentage of emerged seedlings.

Cold test: conducted with four replicates of 50 seeds, on paper towels moistened with an amount of distilled water equivalent to 2.5 times the weight of the paper. After seeding, the rolls were placed inside plastic bags, sealed and kept in a B.O.D type chamber at $10^{\circ} \mathrm{C}$ for five days. After this period, they were removed from the plastic bags and transferred to a germinator at $25{ }^{\circ} \mathrm{C}$, where they remained for four days when the number of normal seedlings was determined (Brasil, 2009).

Electrical conductivity test: four replicates of 50 seeds per lot weighing $0.001 \mathrm{~g}$ were placed in plastic cups containing $75 \mathrm{ml}$ of distilled water in germination chambers at $25{ }^{\circ} \mathrm{C}$ for 24 hours. After this period, the electrical conductivity of the solution was determined with the conductivity meter model TEC-4MP and the mean values were calculated and expressed in $\mu \mathrm{S} \mathrm{cm}^{-1} \mathrm{~g}^{-1}$ of seed.

Image analysis in the Seedling Analysis System $\left(S A P L^{\circledR}\right)$ : initially the seeds were placed to germinate, following the methodology proposed by Nakagawa et al. (1999), aiming to grow seedlings. Four replicates of 20 seeds per lot were used. The seeds were distributed along a line drawn on the upper third of the paper towel, longitudinally. The rolls were packed in plastic bags, placed vertically in the germinator for a period of seven days at $25^{\circ} \mathrm{C}$. On the seventh day the seedlings were transferred from the paper towel to a blue staining $(40 \times 60 \mathrm{~cm})$ sheet containing nine $5 \mathrm{~cm}$ wide cells, divided by white bands (Figure 1). The upper corner of the first cell on the right was assigned to a scale, and the rest of the cells were occupied individually by each seedling. 

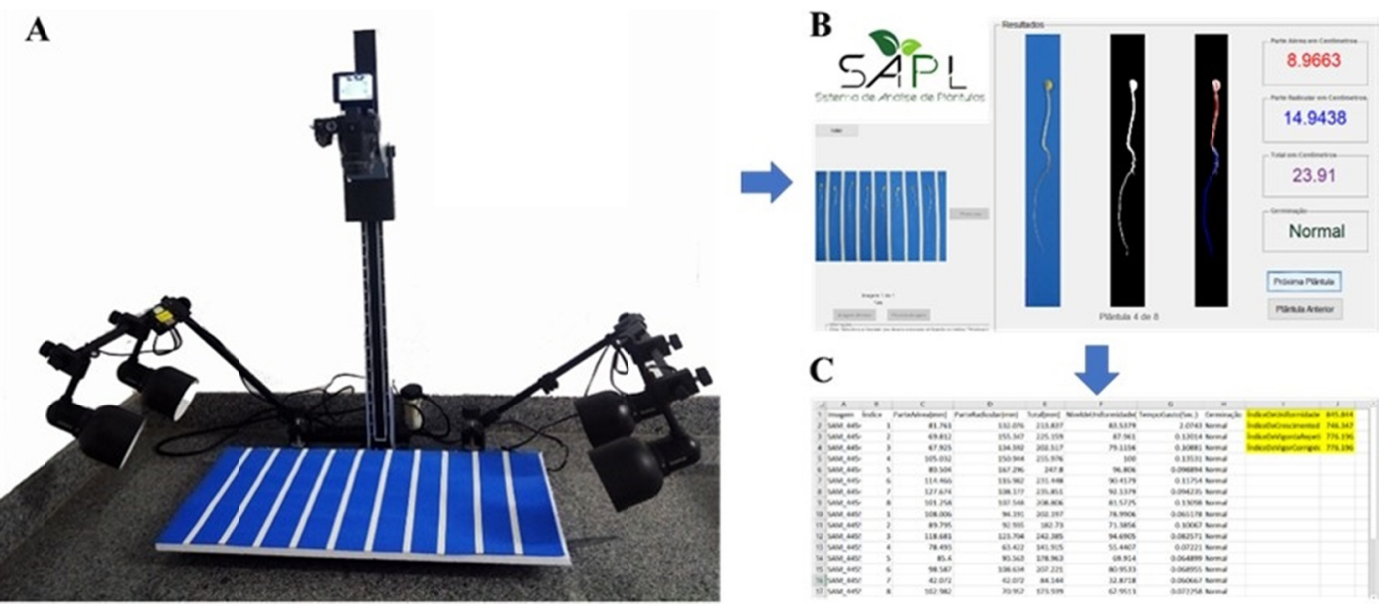

Figure 1. Photographical base used for image acquisition (A), individual processing of seven-day old soybean seedlings (B) and file generated after seedling analysis

Images were acquired using a Samsung digital camera, model DV300F maintained at a fixed height and field vision $(60 \mathrm{~cm})$. The images obtained were entered into the default file selected in the SAPL ${ }^{\circledR}$ software, installed on the Dell Inspiron 5437 computer, with Windows 10 operation system. Afterwards, the specific fields were filled out in the software, in which the proportions 80:20, 70:30, 60:40, growth index and uniformity, respectively, were entered to calculate the vigor index. After recording the initial values, the images of the seedlings were uploaded per repetition and lot.

SAPL ${ }^{\circledR}$ provided measurements of the length of primary root, shoot and entire seedlings, as well as uniformity, growth, vigor and corrected vigor indexes. These indices were defined by Sako et al. (2001), except the corrected vigor index, expressed by the following equation: $\mathrm{IVC}=(\mathrm{wc} \cdot \mathrm{C}+\mathrm{wu} \cdot \mathrm{U}) \cdot \mathrm{germ}$, where, $\mathrm{IVC}=$ corrected vigor index; $\mathrm{wc}=$ weight for growth index; $\mathrm{C}=$ growth index; $\mathrm{wu}=$ weight for uniformity index; $\mathrm{U}=$ uniformity index.

Design and statistical analysis: the experiment was conducted using a completely randomized experimental design. Data were subject to variance analysis (ANOVA). After confirming the normal distribution of errors through the Shapiro-Wilk test, the means were compared using the Student Newman Keuls-SNK test $(p \leq 0.05)$. Subsequently, Pearson's simple correlation coefficients (r) were calculated for all combinations between the seed quality assessment tests, where the significance of the $\mathrm{r}$ values was determined by the $\mathrm{t}$ test $(p \leq 0.05)$. Multivariate analysis of major components (PCA) was also performed. The software used in the statistical analyses was the R (R Development Core Team, 2014).

\section{Results and Discussion}

In The seed moisture content varied from 7.3 to $8.4 \%$ (Figure 2A), indicating that the seed lots may have their physiological quality compared to each other, without being compromised by this factor (Marcos-Filho, 2016). Through the results of the germination test, differences in viability between the lots (Figure 2B) were identified, with lot 4 responding with a lower percentage of normal seedlings, although not differing from lot 3 . For all lots, germination was observed within the standards for sale of soybean seeds, that is, greater than $80 \%$ of germination (Brasil, 2013), indicating high viability of the seeds. 
A
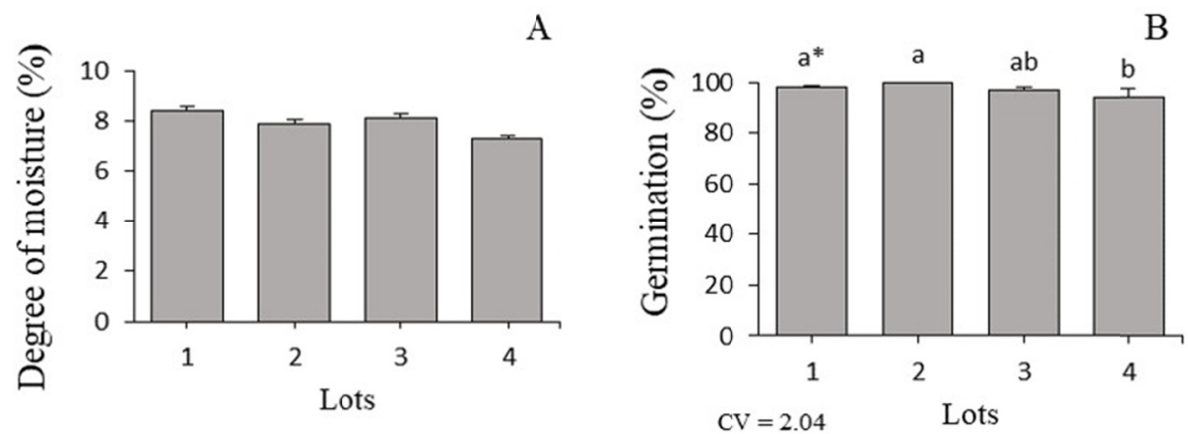

Figure 2. Degree of moisture and percentage of normal seedlings from four soybean seed lots with different levels of physiological quality

Note. * Significant effect by $\mathrm{F}$ test at $5 \%$ probability. Averages followed by the same letter do not differ from one another by the SNK test, at $5 \%$ probability. CV: coefficient of variation; Bars: standard deviation.

The results of the vigor tests indicated significant differences between the seed lots (Figure 3), which were expected because of the difference in viability between them (Figure 2). However, the aim of this study was to use lots with different levels of physiological quality to verify the efficiency of vigor evaluation methods.

Based on the first germination count test (Figure 3A), it was possible to verify differences between lots, so that lots 1 and 2 differed from lots 3 and 4, with higher and lower performance, respectively. According to Marcos Filho (2015), higher values in this test indicate faster germination and, consequently, greater vigor.
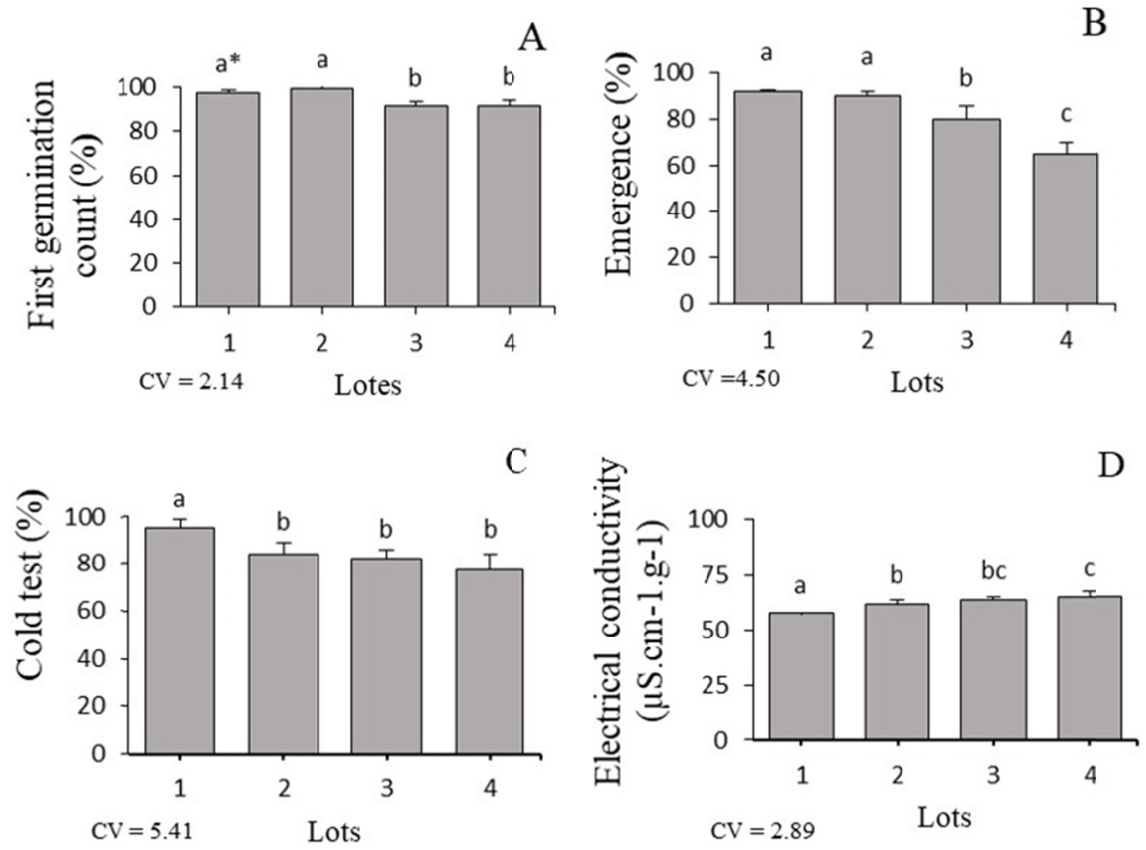

Figure 3. Vigor of four soybean seed lots determined by different traditional tests

Note. * Significant effect by $\mathrm{F}$ test at 5\% probability. Means followed by the same letter do not differ from one another by the SNK test at 5\% probability. CV: coefficient of variation; Bars: standard deviation.

In the emergence test it was possible to differentiate the lots in relation to the percentage of emerged seedlings into three levels of vigor (Figure 3B), categorizing lots 1 and 2 as high vigor, lot 3 of intermediate vigor, and lot 4 of low vigor. This test was shown in this study to be one of the most sensitive for ranking vigor. According to Silveira et al. (2002), the emergence test can be considered the best indicative to infer the vigor of seed lots, since there is a closer relationship with the field conditions to which the seeds will be subject at the time of sowing. 
Through the cold test (Figure 3C) and electrical conductivity test (Figure 3D), superior performance was found for lot 1 in relation to the others. However, the cold test was only able to separate the lots into two levels of vigor, as with the first germination count. Electrical conductivity enabled the identification of lots of intermediate behavior, making a categorization into three levels of vigor possible.

These results evidenced the relationship between these tests with cell membrane integrity and the deterioration process, since in the cold test the seeds are exposed to low temperatures, generating thermal stress and difficulties in the reorganization of the cell membranes during imbibition. In this situation the chances of survival of vigorous seeds are higher (Fanan et al., 2006). As for the electrical conductivity test, it is based on loss of ions, sugars and metabolites in view of the alteration of membrane integrity (Fessel et al., 2003), i.e. higher conductivity indicates loss of membrane integrity in the deterioration process and lower efficiency of repair mechanisms when the seeds are embedded.

Evaluating the vigor through the analysis of seedlings images with seven days, it was possible to identify differences in the physiological potential of the seed lots by means of most of the parameters assessed (Figure 4).

A

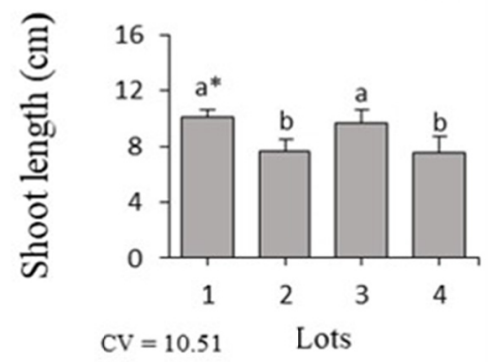

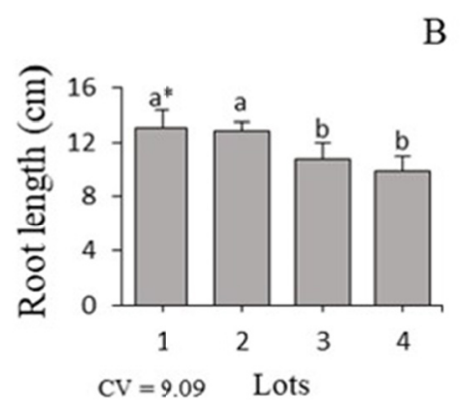

B

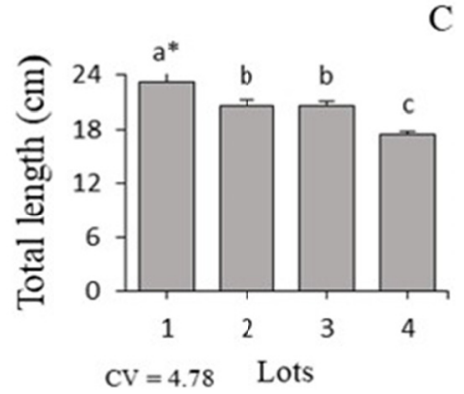

$\mathrm{D}$

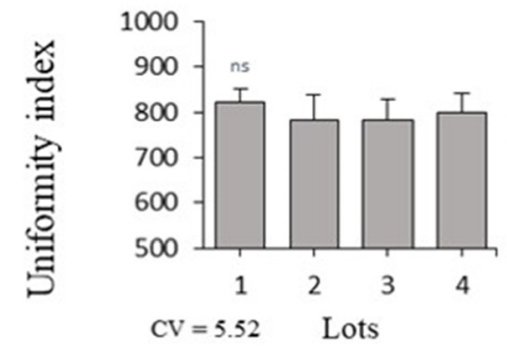

$\mathrm{E}$

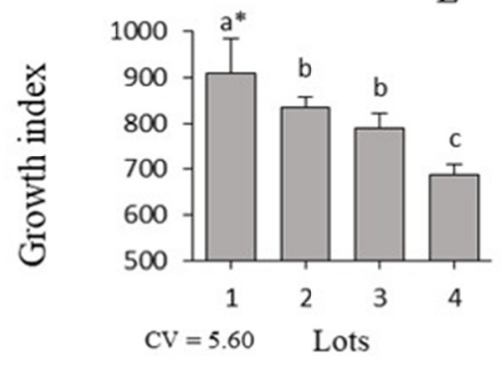

Figure 4. Vigor of four soybean lots determined by image analysis using SAPL ${ }^{\circledR}$ software

Note. ${ }^{*}$ Significant and ${ }^{\mathrm{ns}}$ non-significant effect through $\mathrm{F}$ test at $5 \%$ probability. Means followed by the same letter do not differ from one another by the SNK test at $5 \%$ probability. CV: coefficient of variation; Bars: standard deviation.

From the shoot length of seedlings, it was possible to identify that lot 1 and 3 showed superior performance to the other lots (Figure 4A). However, this result differed in part from the results of the physiological characterization of the lots, since in all tests lot 1 differed from lot 3. However, for the test of the length of soybean seedlings it is recommended to opt for root length results, since they are more sensitive to identify differences in vigor (Vanzolini et al., 2007). In this context, the classification for vigor of primary root length (Figure 4B) was identical to the first germination count test (Figure 3A), with lots 1 and 2 differing from lots 3 and 4, higher and lower performance, respectively.

In the evaluation of seedling total length (Figure 4C), a categorization similar to physiological characterization through the traditional tests was observed, ranking the lots in three levels of vigor. Lot 4 was considered of lower performance, lot 3 of intermediate, and lots 1 and 2 of high performance. Other authors such as Vanzolini et al. (2007), Marcos Filho et al. (2009), Dias et al. (2015), and Wendt et al. (2017) found that adequate development of the seedlings is related to their establishment in the field and seedling length evaluation can help in determining seed vigor, generating reliable results in comparison to the traditional vigor tests. 
Automated seedling length assessment has been considered sensitive at detecting differences in the physiological potential of seeds of several species, especially soybean (Marcos Filho et al., 2009; Medeiros \& Pereira, 2018; Wendt et al., 2017). In addition, their results may be closely related to emergence of seedlings in the field (Vanzolini et al., 2007; Wendt et al., 2017).

For the indexes provided by the $\mathrm{SAPL}^{\circledR}$ software, promising results were observed in evaluating seed vigor, except for the uniformity index. The uniformity index (Figure 4D), which takes into account the difference in length between seedlings of the same lot, did not enable identification of differences in seed vigor, showing itself to be a low sensitivity parameter. Caldeira et al. (2014), and Chiquito et al. (2012) found similar results in the evaluation with the SVIS ${ }^{\circledR}$ software in sunflower and cucumber seeds, respectively, for this same index. In contrast, results obtained by Leão-Araújo et al. (2017) and Silva et al. (2012), using SVIS ${ }^{\circledR}$ software, demonstrate that uniformity of seedling development can provide useful information on the degree of seed deterioration, initial growth potential and uniformity of seedling emergence. Reliable results were also obtained by Sako et al. (2001) and Marcos-Filho et al. (2006), confirming the high potential of seedling uniformity evaluation as indicative of seed vigor.

The values of the growth index (Figure 4E), which takes into account shoot and root length, were closely related to the results obtained in the emergence and electrical conductivity tests. Wendt et al. (2014) found similar results regarding the sensitivity achieved by the growth index when evaluating soybean seeds with the SVIS ${ }^{\circledR}$ software, showing high efficiency of the index in classifying seeds for vigor.

From the results obtained for the vigor index (Figure 5A), it was possible to differentiate the lots into three levels of vigor. Lot 1 was classified as the most vigorous, lots 2 and 3 with intermediate vigor and lot 4 with low vigor. For this test, the lots that achieved higher performance presented seedlings with higher rates of development, growth and uniformity. These higher rates are related to the greater capacity of transformation of seed reserves in the composition and formation of the embryonic axis (Nakagawa et al., 1999).

A
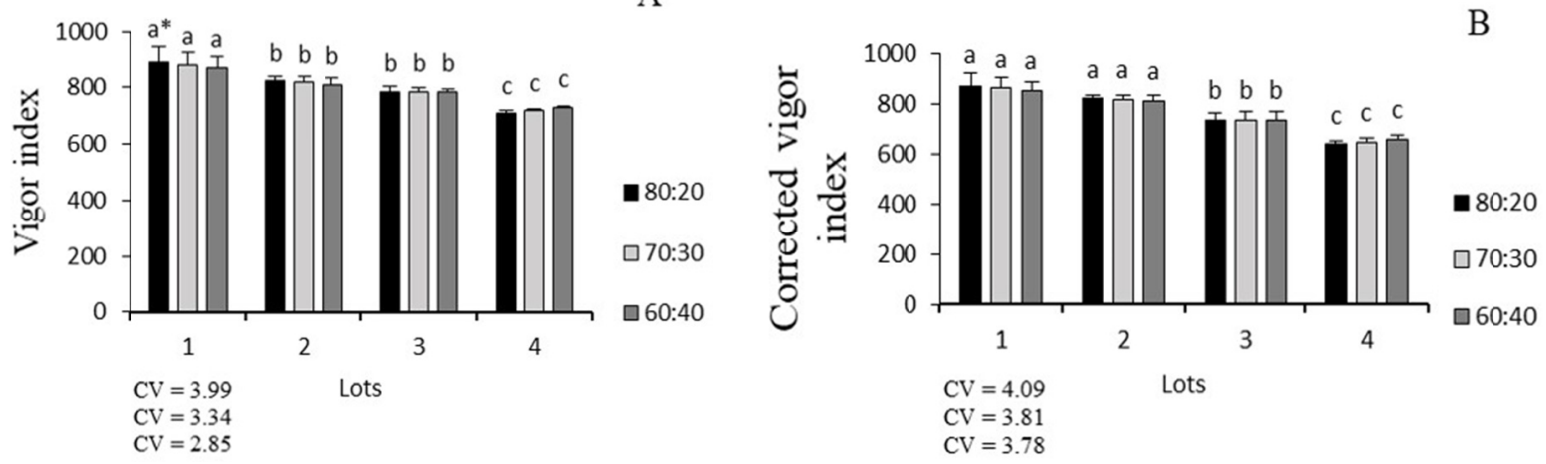

Figure 5. Vigor of four lots of soy determined by image analysis using SAPL ${ }^{\circledR}$ software

Note. * Significant effect by F test at 5\% probability. Means followed by the same letter do not differ from one another by the SNK test at $5 \%$ probability. CV: coefficient of variation; Bars: standard deviation.

For the corrected vigor index (Figure 5B), results similar to those of the initial physiological characterization were obtained, especially for the seedling emergence test, showing sensitivity for the categorization of the lots. By this index, the lots were ranked into three levels of vigor, lots 1 and 2 being high vigor, lot 3 medium vigor, and lot 4 low vigor. Corrected vigor index is an index that considers both seedling length and seed germination, thus supporting a more coherent signaling between viability and vigor (Medeiros \& Pereira, 2018). For Nakagawa et al. (1999), this adjustment is important because there are cases in which the lot presents a low percentage of germination and a high average seedling length on the opposite, a fact that must be taken into account for an efficient and reliable analysis of the lot.

All combinations of proportions in the tested growth/uniformity weights indices (80:20, 70:30, 60:40), both in the vigor index and in the corrected vigor index (Figure 5), allowed seed lot classification similar to those based on the results of other vigor tests, indicating the possibility of using a broader range of proportions. Similar results were found by Chiquito et al. (2012) and Gomes Junior et al. (2014) when working with SVIS ${ }^{\circledR}$ software to analyzing cucumber and bean seeds, respectively. 
Based on the Pearson correlation analysis (Figure 6), it was possible to observe significant correlations between the variables generated by the traditional quality tests and the image analysis. Only the data obtained for the uniformity index and the shoot length did not correlate significantly with any traditional test $(p>0.05)$. Marchi \& Cicero, 2017), evaluating carrot seeds, also observed the absence of correlation between the uniformity index and the traditional tests. In contrast, Gonçalves et al. (2017), working with onion seeds, observed high significant correlation of the uniformity index with the results of the physiological characterization of the seed lots.

\begin{tabular}{|c|c|c|c|c|c|}
\hline & Germ. & $\mathrm{FGC}$ & Emergence & EC & Cold test \\
\hline Shoot length & 0.41 & 0.09 & 0.35 & -0.41 & 0.51 \\
\hline Root length & 0.43 & 0.57 & $0.81^{*}$ & -0.61 & 0.46 \\
\hline Seedling length & 0.58 & 0.48 & $0.83 *$ & $-0.71^{*}$ & $0.66^{*}$ \\
\hline Growth index & 0.55 & 0.55 & $0.87 *$ & $-0.71^{*}$ & 0.61 \\
\hline Uniformity index & 0.26 & 0.29 & 0.01 & -0.19 & 0.48 \\
\hline $\mathrm{V} 80: 20$ & 0.58 & 0.58 & $0.87^{*}$ & $-0.73^{*}$ & $0.67 *$ \\
\hline V70:30 & 0.6 & 0.6 & $0.87 *$ & $-0.74 *$ & $0.71^{*}$ \\
\hline V60:40 & 0.61 & 0.62 & $0.85 *$ & $-0.75 *$ & $0.74 *$ \\
\hline VC $80: 20$ & $0.71 *$ & $0.75^{*}$ & $0.92 *$ & $-0.76^{*}$ & $0.7^{*}$ \\
\hline VC70:30 & $0.72 *$ & $0.77^{*}$ & 0.91 * & $-0.76^{*}$ & $0.72 *$ \\
\hline VC60:40 & $0.74 *$ & $0.79^{*}$ & $0.89 *$ & $-0.75^{*}$ & $0.74^{*}$ \\
\hline
\end{tabular}

Figure 6. Pearson correlation between the variables evaluated by the traditional vigor tests and by image analysis, in seeds and seedlings of four soybean lots $(\mathrm{n}=16$, referring to the replications of each lot)

Note. Germ.: Germination, FGC: First germination count, E: Emergence, EC: Electrical conductivity, V: Vigor index, VC: Corrected vigor index.

The emergence test, considered more sensitive in initial characterization of the lots, correlated significantly with all indices generated from the image analysis $(\mathrm{r}>0.85)$, except for the uniformity index. Other authors working with crambe seeds (Leão-Araújo et al., 2017), wheat (Brunes et al., 2016) and soybean (Medeiros \& Pereira, 2018; Yagushi et al., 2014) also observed a significant correlation between the majority of parameters related to image analysis with traditional tests used. According to Gonçalves et al. (2017), the correlation between traditional tests and image analysis is important for adapting and improving the methodology, and according to Albuquerque et al. (2008), when a great dependence between the variables is observed, one can decide to reduce the number of characteristics evaluated in future experiments.

Based on multivariate principal components analysis (PCA), which was performed using the data set obtained for the four lots studied and the 16 variables evaluated, it is observed that the first two components explained $94.8 \%$ of the variability contained in the data (Figure 7 ). 


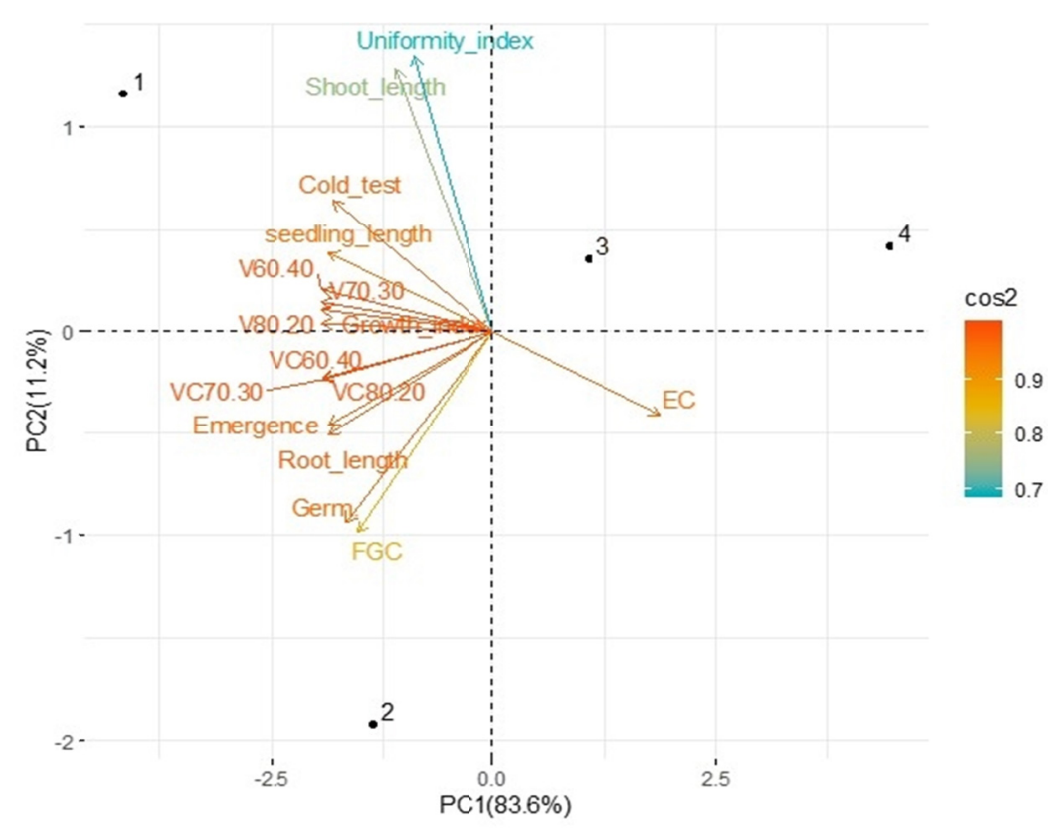

Figure 7. Biplot obtained by grouping the variables related to the physiological quality of the seeds

Note. PC1: Main Component 1, PC2: Main Component 2; Germ.: Germination, FGC: First germination count, E: Emergence, EC: Electrical conductivity, V: Vigor index, VC: Corrected vigor index.

With this, it was possible to explain reliably the behavior of the lots in relation to the physiological characteristics evaluated. The projection of individual plots as vectors in the plane of the first two axes is given in the central ordering diagram, in which the vectors are represented in a color gradient, indicating the representative quality of each variable for the PCA (Figure 7).

Each vector points to the direction in which the characteristic value has the maximum increase through this ordering diagram, so it can be deduced that lots 1 and 2 presented better performance for the variables evaluated, while lot 5 , situated in position opposite and distant from quality vectors, presented lower performance for those characteristics.

It is also observed that most of the vectors related to seedling analysis were close to the vectors of the traditional vigor tests, confirming once again what was observed for the correlation data (Figure 6), high correlation between the parameters of the imagen analysis and the traditional vigor tests.

Despite the use of four lots of soybeans in this study, the results were promising, demonstrating the consistency of SAPL ${ }^{\circledR}$ software in ranking soybean seed lots in different vigor levels. Likewise, the possibility of including $\mathrm{SAPL}^{\circledR}$ as a new technology for phenotyping of soybean seedlings, as well as in evaluating soybean seed quality, is corroborated. It should be emphasized, however, that it is necessary to perform other research with the use of a larger number of lots and different cultivars, in order to ensure greater reliability in the methodology.

\section{References}

Albuquerque, C. J. B., Von Pinho, R. G., \& Silva, R. da. (2008). Produtividade de híbridos de milho verde experimentais e comerciais. Bioscience Journal, 24(2), 69-76. https://doi.org/10.1590/S1413-70542008 000300010

Bornhofen, E., Benin, G., Galvan, D., \& Flores, M. F. (2015). Épocas de semeadura e desempenho qualitativo de sementes de soja. Pesquisa Agropecuária Tropical, 45(1), 46-55. https://doi.org/10.1590/1983-40632015 v4529143

Brasil, Ministério da Agricultura, Pecuária e Abastecimento. (2009). Regras para análise de sementes (p. 395). Secretaria de Defesa Agropecuária. Brasília, SNAD/DNDV/CLAV.

Brasil. (2013). Padrões para a produção e a comercialização de sementes de soja (Glycine max). Brasília, DF: Diário Oficial da República Federativa do Brasil. 
Brunes, A. P., De Souza Araújo, Á., Dias, L. W., Villela, F. A., \& Aumonde, T. Z. (2016). Seedling length in wheat determined by image processing using mathematical tools. Revista Ciência Agronômica, 47(2), 374-379. https://doi.org/10.5935/1806-6690.20160044

Caldeira, C. M., Carvalho, M. L. M. de, Oliveira, J. A., Coelho, S. V. B., \& Kataoka, V. Y. (2014). Sunflower seed vigor determined by computerized seedling analysis. Científica, 42(4), 346-353. https://doi.org/ 10.15361/1984-5529.2014v42n4p346-353

Castan, D. O. C., Gomes-Junior, F. G., \& Marcos-Filho, J. (2018). Vigor-S, a new system for evaluating the physiological potential of maize seeds. Scientia Agricola, 75(2), 167-172. https://doi.org/10.1590/1678992x-2016-0401

Chiquito, A. A., Gomes Junior, F. G., \& Marcos-Filho, J. (2012). Assessment of physiological potential of cucumber seeds using the software Seedling Vigor Imaging System ${ }^{\circledR}$ (SVIS $\AA$ ). Revista Brasileira de Sementes, 34(2), 255-263. https://doi.org/10.1590/S0101-31222012000200010

Dias, M. A. N., Mondo, V. H. V., Cicero, S. M., Gonçalves, N. R., \& Silva, C. A. T. da. (2015). Vigor tests association as an alternative for precise and efficient assessment of maize seed quality. Revista Caatinga, 28(3), 93-99. https://doi.org/10.1590/1983-21252015v28n311rc

Fanan, S., Medina, P. F., Lima, T. C., \& Filho, J. M. (2006). Avaliação do vigor de sementes de trigo pelos testes de envelhecimento acelerado e de frio. Revista Brasileira de Sementes, 28(2), 152-158. https://doi.org/ 10.1590/S0101-31222006000200021

FAO. (2014). Statistical data bases: Agriculture. Retrieved from http://www.fao.org/statistics/databases/en

Fessel, S. A., Sader, R., Paula, R. C. de, \& Galli, J. A. (2003). Avaliação da qualidade física, físiológica e sanitária de sementes de milho durante o beneficiamento. Revista Brasileira de Sementes, 25(1982), $70-76$. https://doi.org/10.1590/S0101-31222003000400010

Gomes, J., Francisco, G., Mondo, V. H. V, Cicero, S. M., Miller, B., \& Bennett, M. A. (2009). Evaluation of priming effects on sweet Corn seeds by SVIS. Seed Technology, 31(1), 95-100.

Gomes, J., Francisco, G., Chamma, H. M. C. P., \& Cicero, S. M. (2014). Automated image analysis of seedlings for vigor evaluation of common bean seeds. Acta Scientiarum. Agronomy, 36(2), 195-200. https://doi.org/ 10.4025/actasciagron.v36i2.21957

Gonçalves, N. R., Cicero, S. M., Abud, H. F., Gonçalves, N. R., Cicero, S. M., \& Abud, H. F. (2017). Seedling image analysis and traditional tests to evaluate onion seed vigor. Journal of Seed Science, 39(3), $216-223$. https://doi.org/10.1590/2317-1545v39n3160444

Leão-Araújo, E. F., Faria, J., Barboza, C., Marcos-Filho, J., \& Vieira, R. D. (2017). Controlled deterioration test and use of the Seed Vigor Imaging System (SVIS $\left.{ }^{\circledR}\right)$ to evaluate the physiological potential of crambe seeds. Journal of Seed Science, 39(4), 393-400. https://doi.org/10.1590/2317-1545v39n4177911

Marchi, J. L. de, \& Cicero, S. M. (2017). Use of the software Seed Vigor Imaging System (SVIS®) for assessing vigor of carrot seeds. Scientia Agricola, 74(6), 469-473. https://doi.org/10.1590/1678-992x-2016-0220

Marcos-Filho, J., Bennett, M. A., McDonald, M. B., Evans, A. F., \& Grassbaugh, E. M. (2006). Assessment of melon seed vigour by an automated computer imaging system compared to traditional procedures. Seed Science and Technology, 34(2), 485-497. https://doi.org/10.15258/sst.2006.34.2.23

Marcos-Filho, J. (2016). Seed Physiology of Cultivated Plants. ABRATES, Brazil.

Marcos Filho, J. (2015). Seed vigor testing: An overview of the past, present and future perspective. Scientia Agricola, 72(4), 363-374. https://doi.org/10.1590/0103-9016-2015-0007

Marcos Filho, J., Kikuti, A. L. P., \& Lima, L. B. de. (2009). Métodos para avaliação do vigor de sementes de soja, incluindo a análise computadorizada de imagens. Revista Brasileira de Sementes, 31(1), $102-112$. https://doi.org/10.1590/S0101-31222009000100012

Medeiros, A. D. de, \& Pereira, M. D. (2018). SAPL ${ }^{\circledR}$ : A free software for determining the physiological potential in soybean seeds. Pesquisa Agropecuária Tropical, 48(3), 222-228. https://doi.org/10.1590/1983-40632018 v4852340

Medeiros, A. D. de, Silva, J. A., \& Pereira, M. D. (2018). Processamento digital de imagens na determinação do vigor de sementes de milho. Revista Brasileira de Ciências Agrárias, 3, 1-12. https://doi.org/10.5039/ agraria.v13i3a5540 
Nakagawa, J., Krzyzanowski, F. C., Vieira, R. D., \& França Neto, J. D. B. (1999). Testes de vigor baseados no desempenho das plântulas. In F. C. Krzyananowski, R. D. Vieira, \& J. B. França-Neto (Eds.), Vigor de sementes: conceitos e testes (pp. 9-13). Londrina, PR: Abrates.

$\mathrm{R}$ Development Core Team. (2014). R: A language and environment for statistical computing. Vienna, Austria: $\mathrm{R}$ Foundation for Statistical Computing.

Sako, Y., Mcdonald, M. B., Fujimura, K., Evans, A. F., \& Bennett, M. A. (2001). A system for automated seed vigour assessment. Seed Science and Technology, 29(3), 625-636.

Silva, P. P. da, Barros, A. C. S. A., Marcos-Filho, J., Gomes-Junior, F. G., \& Nascimento, W. M. (2017). Assessment of squash seed vigor using computerized image analysis. Journal of Seed Science, 39(2), 159-165. https://doi.org/10.1590/2317-1545v39n2171177

Silva, V. N., Gomes Junior, F. G., \& Cicero, S. M. (2012). Computerized imaging analysis of seedlings for assessment of physiological potential of wheat seeds. Revista Brasileira de Sementes, 34(4), 589-596. https://doi.org/10.1590/S0101-31222012000400009

Silveira, M. A. M., Villela, F. A., \& Tillmann, M. Â. A. (2002). Comparação de métodos para avaliação da qualidade fisiológica em sementes de calêndula. Revista Brasileira de Sementes, 24(2), 24-30. https://doi.org/10.1590/S0101-31222002000100005

Vanzolini, S., Araki, C. A. dos S., Silva, A. C. T. M. da, \& Nakagawa, J. (2007). Teste de comprimento de plântula na avaliação da qualidade fisiológica de sementes de soja. Revista Brasileira de Sementes, 29(2), 90-96. https://doi.org/10.1590/S0101-31222007000200012

Wendt, L., Malavasi, M. M., Dranski, J. A. L., Malavasi, U. C., \& Gomes Junior, F. G. (2017). Relação entre testes de vigor com a emergência a campo em sementes de soja. Brazilian Journal of Agricultural Sciences, 12(2), 166-171. https://doi.org/10.5039/agraria.v12i2a5435

Wendt, Letícia, Gomes Junior, F. G., Zorato, M. de F., \& Moreira, G. C. (2014). Evaluation of the physiological potential of soybean seeds by image analysis. Pesquisa Agropecuária Tropical, 44(3), 280-286. https://doi.org/10.1590/S1983-40632014000300011

Yagushi, J. T., Costa, D. S., \& França-Neto, J. de B. (2014). Saturated salt accelerated aging and computerized analysis of seedling images to evaluate soybean seed performance. Journal of Seed Science, 36(2), 213-221. https://doi.org/10.1590/2317-1545v32n2935

\section{Copyrights}

Copyright for this article is retained by the author(s), with first publication rights granted to the journal.

This is an open-access article distributed under the terms and conditions of the Creative Commons Attribution license (http://creativecommons.org/licenses/by/4.0/). 